\title{
NUTMEG TOXICITY: AMELIORATIVE EFFECT OF AQUEOUS EXTRACT OF GUIERA SENEGALENSIS IN EXPERIMENTAL RAT MODEL
}

\author{
${ }^{1 "}$ Ihegboro, G.O., ${ }^{2}$ Alhassan, A.J, ${ }^{1}$ Owolarafe, T. A., ${ }^{1}$ Ononamadu, C.J., 'Salawu, K., \\ ${ }^{3}$ Afor, E., ${ }^{1}$ Zaharaddeen, I.K., ${ }^{1}$ Edonyabo, M.D. \\ ${ }^{1}$ Department of Biochemistry and Forensic Science, Nigeria Police Academy, Wudil, Kano, Nigeria. \\ ${ }^{2}$ Department of Biochemistry, Faculty of Basic Medical Sciences, Bayero University, Kano, Nigeria. \\ ${ }^{3}$ Department of Chemical Sciences, School of Science and Mathematics, Yaba College of Technology, Yaba. Nigeria \\ Author's email addresses: *IGO-goihegboro@yahoo.com, Tel:+2347031149957, +2349072697344; AAJ \\ ajalhassan@gmail.com,OTA-taowolarafe@gmail.com; OCJ- ononamadecj0016@gmail.com; SK - \\ kailani.salawu@gmail.com; AE- aforemman.65@gmail.com; ZIK-zahidkfr2416@gmail.com; EMD- \\ edonyabo2011@gmail.com.* Author for correspondence \\ (Received: $4^{\text {th }}$ October, 2018; Accepted: $16^{\text {th }}$ April, 2019)
}

\section{ABSTRACT}

\begin{abstract}
Meristic fragrans seeds (also known as nutmeg seed) are commonly used as a spice in various delicacies, as components of teas and soft drinks or mixed in milk and alcohol. The bulk of the spice contains carbohydrates, protein and mineral. The spice possesses phytochemicals which are responsible for its flavoring, coloring, preservative and health-promoting characteristics. The aim of the research was to investigate the ameliorating effect of aqueous extract of $G$. senegalensis against nutmeg toxicity in rat model. The phytochemical content was estimated by either gravimetric or spectrophotometric method, the antioxidant potential was estimated by 2,2-diphenyl-1-picrylhydrazine (DPPH) assay while the biochemical indices were determined by standard protocols. The phytochemical evaluation of G. senegalensis extract (GsE) and M. fragrans extract (MfE) showed high flavonoid content while the saponin content was relatively low. The free radical scavenging activity using 2,2-diphenyl-1-picrylhydrazine (DPPH) assay showed that G. senegalensis extract exhibited stronger antioxidant property compared to $M$. fragrans extract. Nutmeg control group showed increase levels in renal and hepatic function indices but were significantly decreased $(\mathrm{p}<0.05)$ in the groups treated with $200 \mathrm{mg} / \mathrm{kg}$ body weight and $400 \mathrm{mg} / \mathrm{kg}$ body weight of aqueous extract of $\mathrm{G}$. senegalensis. The MDA level was significantly elevated in the nutmeg group, however, it significantly reduced in the treated groups. It can be concluded that the strong antioxidant potential exhibited by $G$. senegalensis may have been responsible for its ameliorative effect against nutmeg-induced toxicity. Since high dietary and long term consumption of nutmeg may have adverse effect on both kidney and liver organs respectively, recommendation on its use in moderation is advisable.
\end{abstract}

Keywords: Phytochemical compounds, 2, 2-diphenyl-1-picrylhydrazine (DPPH), Toxicity, Biochemical Indices, Nutmeg seed.

\section{INTRODUCTION}

Myristica fragrans (Nutmeg) is one of the many food spicing agents. It provides pleasant aroma that stimulates the psychomotor responsible for increased appetite for food (Olayele et al., 2006). M. fragrans is a tropical aromatic evergreen tree that yields an apricot-shaped fruit and belongs to the family known as Myristicaceae. Nutmeg seed is shiny purplish-brown in colour (De Mitto and Frey, 2005). In Nigeria, locally it is called Gujiyadanmiya (Hausa), Ehuruofia (Igbo) and Ariwo (Yoruba). Nutmeg grows well on sufficiently hydrological soil with high content of organic matter with $\mathrm{pH}$ 6.5-7.5 A small fraction of dry matter of the spices contain phytochemicals which are responsible for the flavoring, coloring, preservative and health- promoting characteristics (Has, 2012). Nutmeg has been known for its psychoactive effects derived from the anticholinergic-like hallucinogenic mechanism attributed to myristicin and elemicin (Brenner et al., 1993; Demetriades et al., 2005; Ehrenpreis, et al., 2014). Adults abuse its hallucinogenic properties and children may be at high risk at home, since nutmeg may be widely available as a cooking additive (Mckenna et al., 2004, Ehrenpreis et al., 2014). In the course of its use for both medicinal and nutritional purposes, overdose maybe inevitable and this may pose a great danger to organs of the body (Sangalli and Chiang, 2000; Lee et al., 2005, Andrew and Abieyuwa, 2010). Therefore, the aim of this study is to investigate the protective effect of aqueous extract of G. senegalensis in nutmeg 
induced kidney and liver toxicity. G. senegalensis is a shrub tree widely distributed in the savannah region of West and Central Africa, Nigeria, Senegal, Gambia, Mali, Niger, Burkina Faso and Ghana and belong to the Combretaceae family (Zeljan et al., 1998; Dénou, 2008) and it has been reported to possess strong medicinal property against many diseases (Adedapo et al., 2009).

\section{MATERIALS AND METHODS Plant Materials}

The seeds of Myristica fragrans (nutmeg seed) were obtained from Yan kura Market, Kano while G. senegalensis leaves were obtained from premises of Nigeria Police Academy, Wudil, Kano. Botanical identification was done by Dr. Aminu Jabbi, a plant taxonomist, Department of Biological Science, Nigeria Police Academy, Wudil, Kano.

\section{Preparation of Plant Extracts}

The dried ground seeds of $M$. fragrans $(811 \mathrm{~g}$ ) were macerated in $1000 \mathrm{ml}$ of chloroform and left to stand for 48 hours. It was shaken at regular intervals for 24 hours at room temperature. The extract was filtered using filter paper (Whatman No.1). It was concentrated in open air and covered with perforated foiled paper to prevent contamination. $500 \mathrm{~g}$ of pulverized $G$. senegalensis leaves was macerated in $5000 \mathrm{ml}$ of distilled water and allowed to stay for 48 hours with regular shaking and was thereafter filtered. The filtrate was concentrated on a water bath at 80 ${ }^{\circ} \mathrm{C}$

\section{Animals}

Apparently healthy rats of different sexes weighing between $72 \mathrm{~g}-152 \mathrm{~g}$ were obtained from the Department of Physiology, Bayero University, Kano. The animals were housed in clean and wellventilated cages. The rats were fed with standard feed (Vital feed). The animals were acclimatized for two weeks before induction and treatment.

\section{Nutmeg Toxicity Study}

The rats were fed with nutmeg formulated feed containing $2 \mathrm{~g}$ of nutmeg extract / kilogram body weight of the rat for fifteen days to induce nutmeg toxicity in rat model and then aqueous extract of
G. senegalensis at $200 \mathrm{mg} / \mathrm{kg}$ body weight and 400 $\mathrm{mg} / \mathrm{kg}$ body weight were administered orally for 10 days (Josiah and Ezekiel, 2010).

\section{Experimental Design}

The rats were divided into 4 groups of 5 rats each as follows:

Group 1: Rats received food and water only (Negative control)

Group 2: Rats fed with $2 \mathrm{~g} / \mathrm{kg}$ body weight nutmeg extract formulated feed only (Positive control)

Group 3: Rats fed with $2 \mathrm{~g} / \mathrm{kg}$ body weight nutmeg extract formulated feed and then administered $200 \mathrm{mg} / \mathrm{kg}$ body weight of aqueous extract of G. senegalensis

Group 4: Rats fed with $2 \mathrm{~g} / \mathrm{kg}$ body weight nutmeg extract formulated feed and then administered $400 \mathrm{mg} / \mathrm{kg}$ body weight of aqueous extract of G. senegalensis.

\section{Collection of Blood Samples}

The oral administration of the different concentrations of aqueous extract of $G$. senegalensis lasted for a period of 10 days. The animals were anaesthetized and about $5 \mathrm{ml}$ of blood sample was collected from the neck vein, centrifuged at $3000 \mathrm{rpm}$ for $5 \mathrm{mins}$ and the serum was carefully aspirated with a Pasteur pipette into sample bottles and used within 24 hours for biochemical assays.

\section{Quantitative Phytochemical Analysis of Plant Extracts \\ Estimation of Alkaloid}

The gravimetric method of Harborne, (1973) was adopted. A $0.2 \mathrm{~g}$ of the extract was weighed into a conical flask and $100 \mathrm{ml}$ of $10 \%$ acetic acid in ethanol was added and then allowed to stand for 4 hours. It was then filtered and filtrate concentrated in water bath to one-quarter of the original volume. Concentrated ammonium hydroxide was added drop wise to the extract until precipitation was completed. The whole solution was allowed to settle and the precipitate was collected and washed with dilute ammonium hydroxide solution and then filtered. The residue was dried and weighed to determine alkaloid content. 


\section{Estimation of Flavonoid Content}

Total soluble flavonoid of the extract was determined with aluminum chloride solution using quercetin as standard (Chang et al., 2002). A $1.0 \mathrm{ml}$ of sample solution $(100 \mu \mathrm{g} / \mathrm{ml})$ was mixed with $3 \mathrm{ml}$ of methanol, $0.2 \mathrm{ml}$ of $10 \%$ aluminum chloride, $0.2 \mathrm{ml}$ of $1 \mathrm{M}$ potassium acetate and $5.6 \mathrm{ml}$ of distilled water. The resulting mixture was incubated at room temperature for 30 minutes and the absorbance of the reaction mixture was measured at $415 \mathrm{~nm}$. Different concentrations of quercetin solutions were prepared and the absorbance obtained. The calibration curve was plotted and flavonoid concentration of the extract extrapolated.

\section{Estimation of Phenolic Content}

The amount of phenolic content was estimated by Folin-Ciocateu reagent method as described by Slinkard and Singleton, (1977). A $0.5 \mathrm{ml}$ of extract and $0.1 \mathrm{ml}$ of Folin- Ciocalteu reagent $(0.5$ $\mathrm{N})$ were mixed and incubated at room temperature for 15 minutes. After this, $2.5 \mathrm{ml}$ sodium carbonate solution $(7.5 \% \mathrm{w} / \mathrm{v})$ was added and further incubated for 30 minutes at room temperature. The absorbance of the solution was measured at $760 \mathrm{~nm}$. The concentration of total phenol was expressed as gallic acid equivalent (GAE) ( $\mathrm{mg} / \mathrm{g}$ of dry mass) which is a commonly used reference value.

\section{Estimation of Tannin Content}

The method described by Van Burden and Robinson, (1981) was used. A $0.5 \mathrm{~g}$ of the extract was added to $50 \mathrm{ml}$ of distilled water, and shaken for 1 hour. A $5 \mathrm{ml}$ aliquot of the filtrate was mixed with $2 \mathrm{ml}$ of $0.1 \mathrm{M} \mathrm{FeCl}_{3}$ in $0.1 \mathrm{~N} \mathrm{HCl}$ and $0.008 \mathrm{M}$ potassium ferrocyanide. The absorbance was measured at $720 \mathrm{~nm}$ within 10 minutes.

\section{Estimation of Saponin Content.}

Saponin content of plant extracts was estimated gravimetrically by the method described by Obadoni and Ochuko, (2001). The plant sample was weighed into a conical flask and $10 \mathrm{ml}$ ethanol added to it. The content was then vigorously shaken and kept for 5 hours in a rotary shaker maintained at $55^{\circ} \mathrm{C}$. The solution was then filtered and the residue was re-suspended with ethanol and the extracts were pooled. The pooled extracts were then concentrated in a water bath maintained at $90{ }^{\circ} \mathrm{C}$. The concentrate was mixed with diethyl ether in a separating funnel and shaken vigorously. The aqueous layer was collected while the diethyl ether layer was discarded. The process was repeated thrice and all the aqueous fractions pooled together and then 10 $\mathrm{ml}$ of butanol added. The total saponin content was expressed as $\mathrm{mg} / \mathrm{g}$ sample.

\section{DPPH Free Radical Scavenging Property}

The free radical scavenging activity of the extracts based on the scavenging of the stable 2,2diphenyl-1-picrylhydrazine (DPPH) free radical was estimated spectroscopically by the method of Cuendet et al., (1997). An aliquot of $0.5 \mathrm{ml}$ of extract in ethanol (95\%) at different concentrations $(50,100,150,200$ and $250 \mu \mathrm{g} / \mathrm{ml})$ were mixed with $2.0 \mathrm{ml}$ of reagent solution $(0.004$ $\mathrm{g}$ of DPPH in $100 \mathrm{ml}$ methanol). The control contained only DPPH solution in place of the sample while methanol was used as the blank. The mixture was vigorously shaken and left to stand at room temperature. After 30 minutes the decrease in absorbance of test mixture (due to quenching of DPPH free radicals) was read at $517 \mathrm{~nm}$. The scavenging effect was calculated using the expression:

$$
\% \text { inhibition }=\left[\begin{array}{c}
{\left[A_{0}-A_{1}\right] \times 100} \\
A_{0}
\end{array}\right.
$$

Where $A_{0}$ is the absorption of the blank sample and $A_{1}$ is the absorption of the extract

\section{Biochemical Assays}

The total protein (TP), alanine aminotransferase (ALT), alkaline phosphatase (ALP), aspartate aminotransferase (AST), albumin (ALB), creatinine, urea, potassium ion and chloride ion levels in serum of the rats were evaluated using standard protocols and assay kits from Randox Laboratories Limited, United Kingdom.

\section{Determination of Malodialdehydre (MDA) Level}

The MDA level was evaluated by measuring thiobarbituric acid (TBA) reactive substances described by Ohkawa et al., 1979. $0.5 \mathrm{~g}$ of kidney organ was taken and a homogenate was prepared 
in $360 \mu$ l phosphate buffer (10 mM, pH 7.4) and centrifuged at $13000 \mathrm{rpm}$ for $10 \mathrm{mins}$ at $25^{\circ} \mathrm{C}$. $15 \mu \mathrm{l}$ of the supernatant was mixed with $15 \mu \mathrm{l}$ SDS (8.1\%), $96 \mu \mathrm{l}$ TBA (0.8\%), $96 \mu \mathrm{l}$ acetic acid $(20 \%)$ and $18 \mu$ listilled water and incubated at 90 ${ }^{\circ} \mathrm{C}$ for 60 mins. Afterwards, $60 \mu$ distilled water and $300 \mu \mathrm{ln}$-butanol-pyridine mixture (15:1) was added and the mixture was shaken vigorously and centrifuged at $4000 \mathrm{rpm}$ at $25^{\circ} \mathrm{C}$ for 10 mins. The upper butanol layer was separated and its absorbance was taken at $532 \mathrm{~nm}$.

\section{Determination of Haematological Parameters}

The haematological parameters were determined using Mindary Heamatology analyser for full blood count.

\section{Statistical Analysis}

The data obtained were analyzed using one way ANOVA (Analysis of Variance) using SPSS version 16.0. All data were expressed as mean \pm standard deviation (Mean \pm SD) and the significant difference between groups were considered at $\mathrm{p}<0.05$.

\section{RESULTS}

\section{Phytochemical Constituents}

The phytochemical evaluation of $M$. fragnans and G. senegalensis showed the presence of alkaloids, flavonoids, phenolics, saponin and tannins. From Table 1, the result reveals that flavonoids were most abundant especially in G. senegalensis. The saponin content of $M$. fragrans and $G$. senegalensis were significantly low compared to other phytochemical compounds (Table 1).

Table 1: Levels of Phytochemical Constituents of M. fragrans and G. senegalensis Extracts.

\begin{tabular}{lcc}
\hline Phytochemicals & $\begin{array}{c}\text { M. fragrans extract } \\
(\mathrm{mg} / 100 \mathrm{~g})\end{array}$ & $\begin{array}{l}\text { G.senegalensis extract } \\
(\mathrm{mg} / 100 \mathrm{~g})\end{array}$ \\
\hline Alkaloids & $15.01 \pm 0.55$ & $17.90 \pm 0.23$ \\
Flavonoids & $48.76 \pm 0.24$ & $70.91 \pm 2.23$ \\
Phenolics & $21.61 \pm 0.36$ & $21.61 \pm 2.50$ \\
Saponins & $0.06 \pm 0.00$ & $0.18 \pm 0.02$ \\
Tannins & $32.02 \pm 0.06$ & $30.93 \pm 0.05$ \\
\hline
\end{tabular}

Values were in triplicates and represented statistically as MEAN \pm SD

\section{In vitro Antioxidant Activity}

The 2,2-diphenyl-1-picrylhydrazine (DPPH) result showed that the antioxidant activity of the plant extracts investigated increased as the concentration of the extracts increased as shown in table 2. The G. senegalensis exhibited stronger antioxidant activity when compared with $M$. fragrans, however, it was significantly lower compared to ascorbic acid at $\mathrm{p}<0.05$.

Table 2: DPPH Antioxidant Properties of M. fragrans and G. senegalensis Extracts.

\begin{tabular}{clrc}
\hline $\begin{array}{c}\text { Concentration } \\
(\mu \mathrm{g} / \mathrm{ml})\end{array}$ & $\begin{array}{l}\text { Control } \\
(\% \text { inhibition })\end{array}$ & $\begin{array}{c}\text { M. fragrans } \\
(\% \text { inhibition })\end{array}$ & $\begin{array}{c}\text { G. senegalensis } \\
(\% \text { inhibition })\end{array}$ \\
\hline 50 & $86.02 \pm 0.21^{\mathrm{a}}$ & $32.51 \pm 3.83^{\mathrm{b}}$ & $9.93 \pm 0.45^{\mathrm{b}}$ \\
100 & $86.50 \pm 0.06^{\mathrm{a}}$ & $35.04 \pm 1.97^{\mathrm{b}}$ & $43.76 \pm 1.02^{\mathrm{b}}$ \\
150 & $86.52 \pm 0.03^{\mathrm{a}}$ & $36.39 \pm 0.74^{\mathrm{b}}$ & $48.37 \pm 4.73^{\mathrm{b}}$ \\
200 & $86.57 \pm 0.30^{\mathrm{a}}$ & $37.06 \pm 2.31^{\mathrm{b}}$ & $50.96 \pm 0.57^{\mathrm{b}}$ \\
250 & $86.60 \pm 0.11^{\mathrm{a}}$ & $37.96 \pm 2.31^{\mathrm{b}}$ & $53.07 \pm 0.28^{\mathrm{b}}$ \\
\hline
\end{tabular}

Values were in triplicates and were represented as Mean \pm S.D. Same superscript as the control across the row show no significant difference between control and other groups 
Effect of Aqueous Extract of G. senegalensis on Liver Function Indices

The total protein level was found to be remarkably increased in those administered with $400 \mathrm{mg} / \mathrm{kg}$ body weight of $G$. senegalensis compared to those fed with $2 \mathrm{~g} / \mathrm{kg}$ body weight of nutmeg formulated feed. There was slight increase observed in those administered with $200 \mathrm{mg} / \mathrm{kg}$ body weight of $G$. senegalensis compared to those fed with $2 \mathrm{~g} / \mathrm{kg}$ body weight of nutmeg formulated feed only. The total protein in the control group was significantly lower compared to the nutmeg and treated groups. There was significant increase in albumin level in both the control and treated groups compared to those fed with $2 \mathrm{~g} / \mathrm{kg}$ body weight nutmeg formulated feed only. The alanine aminotransferase level was elevated in those fed with $2 \mathrm{~g} / \mathrm{kg}$ body weight of nutmeg formulated feed but significantly reduced in the treated groups especially in those administered with $200 \mathrm{mg} / \mathrm{kg}$ body weight of aqueous extract of $G$. senegalensis and the control group. The aspartate aminotransferase level was found to be elevated in those fed with $2 \mathrm{~g} / \mathrm{kg}$ body weight nutmeg formulated feed only but significantly reduced in the treated groups and also the control group. Table 3 showed that the level of alkaline phosphatase increased in those fed with $2 \mathrm{~g} / \mathrm{kg}$ body weight nutmeg formulated feed but significantly reduced in the treated groups and the control group.

Table 3: Effect of Aqueous Extract of G.Senegalensis on Liver Function Indices (LFI) in Nutmeg Fed Rats.

\begin{tabular}{|c|c|c|c|c|}
\hline Kidney function indices & Control & Nutmeg only & $\begin{array}{l}\text { Nutmeg+200 mg/kg } \\
\text { of G. senegalensis } \\
\text { extract }\end{array}$ & $\begin{array}{l}\text { Nutmeg }+400 \mathrm{mg} / \mathrm{kg} \\
\text { of G.senegalensis } \\
\text { extract }\end{array}$ \\
\hline Total Protein $(\mathrm{g} / \mathrm{dl})$ & $4.54 \pm 0.55^{a}$ & $6.37 \pm 0.28^{\mathrm{bc}}$ & $6.41 \pm 0.28^{\mathrm{bc}}$ & $9.20 \pm 0.80^{\mathrm{bd}}$ \\
\hline Albumin $(\mathrm{g} / \mathrm{dl})$ & $3.86 \pm 0.37 \mathrm{a}$ & $3.11 \pm 0.15^{\mathrm{bc}}$ & $3.25 \pm 0.85^{\mathrm{bc}}$ & $3.71 \pm 0.11^{a c}$ \\
\hline $\begin{array}{l}\text { Alanine } \\
\text { aminotransferase } \\
\text { (ALT) (IU/L) }\end{array}$ & $3.16 \pm 1.32^{\mathrm{a}}$ & $5.20 \pm 1.60 \mathrm{bc}$ & $1.93 \pm 0.55^{b d}$ & $3.89 \pm 0.50^{\mathrm{bd}}$ \\
\hline $\begin{array}{l}\text { Aspartate } \\
\text { aminotransferase } \\
(\text { AST) }(\mathrm{IU} / \mathrm{L})\end{array}$ & $0.71 \pm 0.30^{a}$ & $1.93 \pm 0.10^{\mathrm{bc}}$ & $0.75 \pm 0.12^{\mathrm{bd}}$ & $0.85 \pm 0.50^{\text {bd }}$ \\
\hline $\begin{array}{l}\text { Alkaline } \\
\text { Phosphatase } \\
\text { (ALP) (IU/L) }\end{array}$ & $1194.90 \pm 9.10^{a}$ & $1301.50 \pm 14.44 \mathrm{bc}$ & $1183.80 \pm 16.00^{\mathrm{bd}}$ & $1268.20 \pm 8.24 \mathrm{bd}$ \\
\hline
\end{tabular}

Values were in triplicates and represented as MEAN \pm S.D. The same superscript as control across the row shows no significant difference between the control and other groups while same superscript as nutmeg only across the row shows no significant difference between nutmeg only and treated groups at $\mathrm{p}<0.05$. KEY: IU $/ \mathrm{L}=$ International unit/Liter

\section{Effect of Aqueous Extract of G. senegalensis on Kidney Function Indices}

There was an increase in creatinine level in rats fed with $2 \mathrm{~g} / \mathrm{kg}$ body weight nutmeg formulated feed but was found to be lowered in the treated groups and negative control group (Table 4). It was observed that there was no significant difference between control and other groups and between those fed with nutmeg only and the treated groups. The urea level was significantly low $(\mathrm{P}<0.05)$ in the control group when compared to other treated groups. However, nutmeg group (positive control) was lower when compared with the treated groups However, the urea level of those administered with $400 \mathrm{mg} / \mathrm{kg}$ body weight of aqueous extract of $G$. senegalensis was higher compared to those administered with $200 \mathrm{mg} / \mathrm{kg}$ body weight of the plant extract. The potassium ion concentration was significantly higher in group fed with nutmeg only when compared with the treated groups and the control group. The chloride ion concentration in the rats fed with 2 $\mathrm{g} / \mathrm{kg}$ body weight of nutmeg formulated feed was significantly elevated but was reduced in the treated and control groups, however, those administered with $400 \mathrm{mg} / \mathrm{kg}$ body weight of 
aqueous extract of $G$. senegalensis was significant reduced when compared to other groups. The MDA level revealed a significant reduction $(\mathrm{p}<$ $0.05)$ in the control and the treated groups compared to the group fed with nutmeg formulated feed. There was no significant difference observed between the nutmeg group and treated groups.

Table 4: Effect of Aqueous Extract of G. senegalensis on Kidney Function Indices (KFI) in Nutmeg Fed Rats

\begin{tabular}{lllll}
\hline $\begin{array}{l}\text { Kidney function } \\
\text { indices }\end{array}$ & Control & Nutmeg only & $\begin{array}{l}\text { Nutmeg+200 mg/kg } \\
\text { of G. senegalensis } \\
\text { extract }\end{array}$ & $\begin{array}{l}\text { Nutmeg }+400 \mathrm{mg} / \mathrm{kg} \\
\text { of G. senegalensis } \\
\text { extract }\end{array}$ \\
\hline Creatinine $(\mathrm{mg} / \mathrm{dl})$ & $0.88 \pm 0.04 \mathrm{a}$ & $0.93 \pm 0.16 \mathrm{bc}$ & $0.72 \pm 0.18 \mathrm{ac}$ & $0.70 \pm 0.15 \mathrm{ac}$ \\
Urea $(\mathrm{mMol} / \mathrm{l})$ & $0.35 \pm 0.10 \mathrm{a}$ & $0.83 \pm 0.31 \mathrm{bc}$ & $0.93 \pm 0.05 \mathrm{bc}$ & $1.11 \pm 0.12 \mathrm{bd}$ \\
Potassium $(\mathrm{mEq} / \mathrm{l})$ & $6.52 \pm 1.62 \mathrm{a}$ & $8.93 \pm 1.88 \mathrm{bc}$ & $5.83 \pm 1.13 \mathrm{ad}$ & $5.84 \pm 0.82 \mathrm{ad}$ \\
Chloride $(\mathrm{mEq} / \mathrm{l})$ & $107.12 \pm 8.08 \mathrm{a}$ & $116.96 \pm 6.70 \mathrm{bc}$ & $107.80 \pm 4.00 \mathrm{ac}$ & $91.73 \pm 7.77 \mathrm{bd}$ \\
$\mathrm{MDA}(\mu \mathrm{mol} / \mathrm{ml})$ & $2.91 \pm 0.86 \mathrm{a}$ & $5.62 \pm 0.27 \mathrm{bc}$ & $3.90 \pm 0.47 \mathrm{ad}$ & $3.85 \pm 1.17 \mathrm{ad}$ \\
\hline
\end{tabular}

Values were in triplicates and represented as MEAN \pm S.D. The same superscript as control across the row shows no significant difference between the control and other groups while same superscript as nutmeg only across the row shows no significant difference between nutmeg only and treated groups

Effect of Aqueous Extract of G. senegalensis on Haematological Parameters

The white blood cell count (WBC) was found to be low in rats fed with nutmeg only but significantly increased in the control and the rats administered with 200 and $400 \mathrm{mg} / \mathrm{kg}$ body weight respectively of aqueous extract of $G$. senegalensis. From table 5, the red blood cell count (RBC) showed significant decrease in the group fed nutmeg only when compared with the control and group administered with $200 \mathrm{mg} / \mathrm{kg}$ body weight of aqueous extract of $G$. senegalensis while a decrease was observed in the group administered with $400 \mathrm{mg} / \mathrm{kg}$ body weight of aqueous extract of $G$. senegalensis when compared with the control group, nutmeg only and those administered with $200 \mathrm{mg} / \mathrm{kg}$ body weight of aqueous extract of $G$. senegalensis. The haemoglobin level (HGB) was found to be increased in both control and the rats administered with 200 and $400 \mathrm{mg} / \mathrm{kg}$ body weight of aqueous extract of $G$. senegalensis compared to the rats fed with nutmeg only. The mean cell haemoglobin count (MCHC) level was significantly increased in the treated groups compared to the rats fed with nutmeg only but the rats administered with $400 \mathrm{mg} / \mathrm{kg}$ body weight of G. senegalensis were significantly higher. In all the haematological parameters estimated (Table 5), it was only in white blood cell count that significant difference was observed between control and other groups and between rats fed with nutmeg only and those administered with 200 and 400 $\mathrm{mg} / \mathrm{kg}$ body weight of $G$. senegalensis while in other parameters, there was no significant difference between control and other groups and between rats fed with nutmeg only and those administered with 200 and $400 \mathrm{mg} / \mathrm{kg}$ body weight of aqueous extract of G. senegalensis. 
Table 5: Effect of Aqueous Extract of G. Senegalensis on Haematological Parameters in Nutmeg Fed Rats.

\begin{tabular}{lllll}
\hline $\begin{array}{l}\text { Haematological } \\
\text { Parameters }\end{array}$ & Control & Nutmeg only & $\begin{array}{l}\text { Nutmeg+200mg/kg of } \\
\text { G. senegalensis extract }\end{array}$ & $\begin{array}{l}\text { Nutmeg+400mg/kg of } \\
\text { G. senegalensis extract }\end{array}$ \\
\hline WBC $\left(10^{2} / \mu \mathrm{l}\right)$ & $5.26 \pm 2.85^{\mathrm{a}}$ & $4.47 \pm 0.39^{\mathrm{bc}}$ & $8.20 \pm 2.69^{\mathrm{bd}}$ & $9.63 \pm 6.27^{\mathrm{bd}}$ \\
$\mathrm{RBC}\left(10^{5} / \mu \mathrm{l}\right)$ & $8.64 \pm 0.42^{\mathrm{a}}$ & $6.12 \pm 2.48^{\mathrm{ac}}$ & $7.50 \pm 0.43^{\mathrm{ac}}$ & $5.52 \pm 2.73^{\mathrm{ac}}$ \\
HGB $(\mathrm{g} / \mathrm{dl})$ & $15.30 \pm 0.20^{\mathrm{a}}$ & $11.57 \pm 4.65^{\mathrm{ac}}$ & $13.83 \pm 1.00^{\mathrm{ac}}$ & $11.73 \pm 3.49^{\mathrm{ac}}$ \\
HCT $(\%)$ & $56.47 \pm 2.05^{\mathrm{a}}$ & $42.17 \pm 18.59^{\mathrm{ac}}$ & $48.47 \pm 3.72^{\mathrm{ac}}$ & $35.80 \pm 15.95^{\mathrm{ac}}$ \\
$\mathrm{MCV}(\mathrm{fl})$ & $65.40 \pm 0.80^{\mathrm{a}}$ & $67.93 \pm 3.69^{\mathrm{ac}}$ & $64.53 \pm 1.88^{\mathrm{ac}}$ & $66.10 \pm 4.09^{\mathrm{ac}}$ \\
$\mathrm{MCH}(\mathrm{pg})$ & $17.77 \pm 0.65^{\mathrm{a}}$ & $67.93 \pm 3.69^{\mathrm{bc}}$ & $64.53 \pm 1.88^{\mathrm{bc}}$ & $23.43 \pm 7.68^{\mathrm{ac}}$ \\
PLT $\left(10^{5} / \mu \mathrm{l}\right)$ & $131.50 \pm 7.02^{\mathrm{a}}$ & $315.21 \pm 2.81^{\mathrm{ac}}$ & $254.67 \pm 2.35^{\mathrm{ac}}$ & $197.06 \pm 2.51^{\mathrm{ac}}$ \\
LYMPH $(\%)$ & $85.70 \pm 5.60^{\mathrm{a}}$ & $75.63 \pm 12.22^{\mathrm{ac}}$ & $78.93 \pm 10.29^{\mathrm{ac}}$ & $81.50 \pm 10.42^{\mathrm{ac}}$ \\
$\mathrm{MPV}(\mathrm{fl})$ & $6.17 \pm 2.45^{\mathrm{a}}$ & $8.50 \pm 0.21^{\mathrm{ac}}$ & $8.23 \pm 1.32^{\mathrm{ac}}$ & $7.73 \pm 0.81^{\mathrm{ac}}$ \\
PCT $(\%)$ & $0.63 \pm 0.09^{\mathrm{a}}$ & $0.33 \pm 0.01^{\mathrm{ac}}$ & $0.38 \pm 0.03^{\mathrm{ac}}$ & $0.19 \pm 0.03^{\mathrm{ac}}$ \\
MCHC $(\mathrm{g} / \mathrm{dl})$ & $27.17 \pm 0.65^{\mathrm{a}}$ & $27.96 \pm 1.82^{\mathrm{ac}}$ & $28.53 \pm 0.31^{\mathrm{ac}}$ & $35.03 \pm 9.25^{\mathrm{ac}}$ \\
\hline
\end{tabular}

Values were in triplicates and represented as MEAN \pm S.D. The same superscript as control across the row shows no significant difference between the control and other groups while same superscript as nutmeg only across the row shows no significant difference between nutmeg only and treated groups at $\mathrm{p}<0.05$.

KEYS: WBC $=$ White blood count, $\mathrm{RBC}=$ Red blood count, $\mathrm{HGB}=$ Haemoglobin, $\mathrm{HCT}=$ Total haemoglobin Count, $\mathrm{MCV}=$ Mean cell volume, $\mathrm{MCH}=$ Mean cell haemoglobin, $\quad$ PLT $=$ Platelet count, LYMPH $=$ Lymphocyte, $\mathrm{MPV}=$ Mean packed volume, $\mathrm{PCT}=$ Total packed cell, $\mathrm{MCHC}=$ Mean cell haemoglobin count

\section{DISCUSSION}

Phytochemicals found in a plant may give an insight into the beneficial potential that maybe available in its use. The quantitation of the phytochemicals, showed that flavonoids content was the most abundant in $G$. senegalensis compared to other phytochemicals observed The result of the antioxidant activity of the extracts of $G$. senegalensis leaves and M. Fragnans seed are summarized in table 2. The G. senegalensis extract shows high antioxidant activity when compared to nutmeg extract which may be due to high flavonoid content (Ihegboro et al., 2018). The primary function of the kidney is to maintain homeostasis through its role in the excretion of metabolic wastes and in regulation of intracellular fluid volume, electrolyte and acid-base balance (Orisakwe et al., 2004). This therefore implies that any deviation from this responsibility could partly have been due to toxic effect of exogenous substances or pathogenic infections and this can cause abnormality in kidney function parameters (Andrew and Abieyuwa, 2010). Scientific reports have shown several recorded use of $G$. senegalensis in traditional medicine to treat various illnesses (Fiot et al., 2006). Liver is a vital organ involved in detoxification, secretion, emulsification, synthesis and storage functions and injury to this organ disrupts these activities and causes abnormal elevation or reduction in the levels of liver related indices in the blood (Ranjna, 2003; Wrochekke and Usman, 2013). The serum levels of alanine aminotransferase (ALT), aspartate aminotransferase (AST) and alkaline phosphatase (ALP) in rats fed with nutmeg only were high but significantly reduced with oral administration of $G$. senegalensis extract (Table 3). This may suggest that the aqueous extract of $G$. senegalensis has a therapeutic effect (Diouf, et al., 2000). Creatinine is hydrolysed from creatinine phosphate and has been reported to be a marker of renal function while urea is a waste product of protein metabolism (Adedapo et al., 2009). Table 4 showed significant increase in urea levels in rats administered with 200 and 400 $\mathrm{mg} / \mathrm{kg}$ body weight of aqueous extract of $G$. 
senegalensis compared to the rats fed with nutmeg only while there was significant reduction in creatinine level in rats administered with 200 and $400 \mathrm{mg} / \mathrm{kg}$ body weight of aqueous extract of $G$. senegalensis compared to rats fed with nutmeg only at $\mathrm{p}<0.05$. The elevation in serum potassium and chloride levels may be as a result of tubular and glomerular dysfunction (Olaleye et al., 2006). Malondialdehyde (MDA) is a lipid peroxidation adduct used to measure the level of lipid peroxidation. Although, it is not kidney specific, however, it could be measured to ascertain the level of lipid peroxidative effect in the kidney. The result showed a remarkably elevated level of MDA which may be an indication of nephrotoxicity; however, there was significant decrease at different concentrations after oral administration of G. senegalensis (Table 4). The haematological parameters may give indication on hematopoetic function of the blood. There was significant decrease in the white blood cell count (WBC), red blood cell (RBC), haemoglobin (HGB) levels and other haematological parameters in the rats fed with nutmeg only (Table 5) . Upon oral administration of the aqueous extract of $G$. senegalensis at various concentrations, there was significant improvement in these haematological parameters. This implies that the extract may be good blood and immune defense enhancer. Generally, it was observed that the aqueous extract of $G$. senegalensis at $200 \mathrm{mg} / \mathrm{kg}$ body weight was phytotherapeutically effective compared to the $400 \mathrm{mg} / \mathrm{kg}$ body weight. This is in agreement with previous report (Oshobu and Geidam, 2014).

\section{CONCLUSION}

Aqueous extract of $G$. senegalensis showed a remedial effect at both $200 \mathrm{mg} / \mathrm{kg}$ body weight and $400 \mathrm{mg} / \mathrm{kg}$ body weight respectively. Therefore, it could be concluded that the plant extract ameliorates the effect associated with nutmeg toxicity.

\section{ACKNOWLEDGEMENT}

I want to sincerely appreciate Mr. Haruna Tsoho Bala and Mr. Usman Deneji Aliyu both of the Department of Biochemistry, Bayero University, Kano and Miss Oluchukwu Ihegboro for their technical expertise. I also thank Alfred Samsom and Olua Moses both of the Department of Biochemistry and Forensic Science, Nigeria Police Academy, Wudil, Kano for their input.

\section{REFERENCES}

Adedapo, A.D.A., Osude, Y.O. and Adedapo, A.A. 2009. Blood pressure lowering effect of Adenanthera pavonina seed extract on normotensive rats, Records of Natural Products 3(2): 82-89.

Andrew, O.E. and Abieyuwa, E. 2010. Histological effects of oral administration of nutmeg on the kidneys of adult wistar rats. North. American Journal Medical Science, 2(4): 189-192.

Brenner, N, Frank, O.S amd Knight, E. 1993. Chronic nutmeg psychosis. Journal of the Royal Society Medicine 86: 179-180.

Chang, C., Yang, M. and Wen, H. 2002. Estimation of total flavonoid content in propolis by two complementary colorimetric methods. Journal Food and Drug Analysis 10:178-182.

Cuendet, M., Hostettmann, K. and Potterat, O. 1997. Iridoid glycosides with free radical scavenging properties from Fagraea blumei. Helvetica Chirurgica Acta 80: 73-83.

Demetriades, A.K., Wallman, P.D., McGuiness, A. and Gavalas, M.C. 2005. Low cost, high risk, accidental nutmeg intoxication. Emergence Medical Journal 22(3): 223225.

DeMitto, L and Frey, R.J 2000. In J.L Longe $\left(2^{\text {nd }}\right.$ ed), The Gale encyclopedia of alternative medicine, Formington Hills Michiga: Thomson/Gale. Pp 1461-1463.

Dénou, A. 2008. Contribution à l'étude des problèmes de conservation de la forme sirop des médicaments traditionnels. Thèse de Pharmacie, FMPOS, Bamako. P 82

Diouf, A., Cisse, A., Gueye, S.S., Mendes, V. and Siby, T. 2000. Toxicological study of $G$. senegalensis Lam (Combretaceae). Dakar Medical Journal 45: 89-94.

Ehrenpreis, J.E., Deslauriers, C., Lank, P., Armstrong, P.K., and Leikin, J.B. (2014): -Nutmeg poisonings: A retrospective 
review of 10years experience from the Illinois poison center, 20012011". Journal of Medical Toxicology (2):148-151.

Fiot, J., Sanon, S. and Azas, N. 2006. Phytochemical and pharmacological study of roots and leaves of $G$. senegalensis. Journal Ethno Pharmacology 106(2):173-178.

Has, A.T.C. 2012. The value of Zizyphus muritiana and Myristica fragrans as a new drug discovery in the field of neuroscience. Orient Neuron Nexus 3(1): 14-18.

Harbourne, J.B. 1973. Phytochemical methods, London. Chapman and Hall Limited. Pp 49-188.

Ihegboro, G.O., Ononamadu, C.J., Owolarafe, A.T., Afor, E., and Zaharadeen, I.K. 2018. Antioxidants in plant extracts may contribute to the modulation of their toxicity: An insight with Allium cepa model. Nigeria Society of Experimental Biology Journal 18(2): 92-104.

Josiah, O.A and Ezekiel, U.N. 2010, Histological effects of long term consumption of nutmeg on the medial geniculate body of adult wistar rats. North American Journal of Medical Science 2(3):134-137.

Lee, B.K., Kim, J.H. and Jung, J.W. 2005. Myristicin induced neurotoxicity in human neuroblastoma SK-N-SH cells. Toxicology Letter 157: 49-56.

McKenna, A., Nordt, S.P. and Ryan, J. 2004. Acute nutmeg poisoning. European Journal Emergence 11(4): 240-241.

Obadoni, B.O. and Ochuko, P.O. 2001. Phytochemical studies and comparative efficacy of the crude extracts of some homeostatic plants in Edo and Delta states of Nigeria. Global Journal of Pure and Applied Sciences 8(2): 203-208.

Ohkawa, H., Ohishi, N. and Yagi, K. 1979. Assay for lipid peroxides in animal tissues by thiobartauric acid reaction. Analytical
Biotechnology 95:351-358.

Olaleye M.T., Akinmoladun, A.C. and Akindahunsi, A.A. 2006. Antioxidant properties of Myristica fragrans and its effect on selected organs of albino rats. African Journal Biotechnology 5(13): 1274-1278.

Orisakwe, O.E., Husaini, D.C. and Afonne, O.J. 2004. Testicular effects of sub-chronic administration of Hibiscus sabdariffa calyx aqueous extract in rats, Reproductive Toxicology 18(2): 295-298.

Oshobu, M.A. and Geidam, M.A. 2014. Effects of aqueous ethanolic extract of the leaves of G. senegalensis (Combretaceae) on liver Function in Wistar Strain albino rats. International Journal Science Research Management (IJSRM) 2(3): 611-615.

Ranjna, C. 2003. Practical Clinical Biochemistry Methods and Interpretation (3nd Ed.), Jaypee Brothers Publishers.

Sangalli, B.C. and Chiang, W. 2000. Toxicology of nutmeg abuse. Clinical Toxicology 38(6): 671-678.

Slinkard, K. and Singleton, V.L. 1977. Total phenol analysis: Automation and comparison with manual methods. American Journal Ecology Viticulture 28: 49-55.

Van-Burden, T.P. and Robinson, W.C. 1981. Formation of complexes between protein and Tannin acid. Journal Agriculture Food Chemistry, 1:77-82.

Wurochekke1, A.U. and Usman, S. 2013. Biochemical effects on the Liver and Kidney of Rats administered aqueous leaf extract of G. Senegalensis. International Journal Pure Applied Science Technology 19(2): 61-65.

Zeljan, M., Marica, M. and Franz, B. 1998. Flavonoids of G. senegalensis-Thin layer chromatography and numerical methods. Croatica Chemica Acta 71(1):69-79. 